\title{
Reading the silence: Canadian library responses to racial injustice
}

\section{Lire le silence : les réponses des bibliothèques canadiennes à l'injustice raciale}

\author{
Amber Matthews \\ Western University
}

\begin{abstract}
This paper presents the findings of a research study on the formal response of the Canadian library community to the mass Black Lives Matter (BLM) social movement in the wake of George Floyd's death and the resulting global protests over the summer of 2020. The study employed mixed-method content analysis and its principal goals were to (a) identify formal responses between May to August 2020; (b) analyze themes across how the Canadian library community views and situates itself within conversations of racial justice; and (c) identify the scale and scope of commitments made for future accountability and research. The results show that one third (34\%) of the Canadian library community formally responded with an organizational statement and even less situated their organizations as contributors to systemic racism in Canadian society.
\end{abstract}

Keywords: anti-racism, Black Lives Matter, social justice, libraries, librarianship, policy

Résumé : Cet article présente les résultats d'une étude de recherche sur la réponse formelle de la communauté des bibliothèques canadiennes au mouvement social Black Lives Matter (BLM) à la suite de la mort de George Floyd et des manifestations mondiales qui en ont résulté au cours de l'été 2020. Une analyse de contenu à méthodes mixtes a été utilisée. Les principaux objectifs de l'étude étaient de (a) identifier les réponses formelles entre mai et août 2020 ; (b) analyser les thèmes de la façon dont la communauté des bibliothèques canadiennes se perçoit et se situe dans les conversations sur la justice raciale; et (c) identifier l'ampleur et la portée des engagements pris dans le futur concernant la responsabilité et la recherche. Les résultats montrent qu'un tiers (34\%) de la communauté des bibliothèques canadiennes a officiellement répondu par l'entremise d'un énoncé organisationnel et une plus faible proportion a désigné leur organisation comme contributrice au racisme systémique dans la société canadienne.

Mots clés : antiracisme, Black Lives Matter, justice sociale, bibliothèques, bibliothéconomie, politique 
"We cannot begin to right a wrong, or grieve a loss, or mend a system, without first acknowledging the wrong has been done, the loss that has occurred, and the system that is broken." -- Kathy Hogarth and Wendy L. Fletcher, A Space for Race, 2018

\section{Introduction}

Library and information science (LIS) encompass a unique and often perplexing body of scholarship and practice. Although it rightfully asserts core values that include accessibility, equity, and social responsibility, the field has often framed its work as an apolitical and neutral interlocutor between information and communities, be they the university, the general public, or elsewhere (Canadian Federation of Library Associations 2017). Notwithstanding brave exceptions, Canadian libraries along with adjacent higher education and professional associations have also understated the profound role that librarianship has played in shaping power relations and dominant perceptions of what historically and contemporarily constitutes knowledge. In a description of Canada's relationship with Indigenous and Black communities, Canadian anti-Black racism activist and writer Desmond Cole (2020) writes that "ours is a humble colonialism" (107). This poignant account provides incredible insight into Canadian librarianship as well. While humble and quiet about a disciplinary history that is intricately bound to the social, historical, and cultural dominance of whiteness, the real effects of this colonial ordering and structure are inescapable.

Though libraries may have historically imagined and publicly positioned themselves as neutral and objective, critical library scholars have done important work to problematize how the structural foundations of white supremacy are found and replicated in our work (Espinal 2001; Hathcock 2015; Hathcock and Sendaula 2017; Honma 2005; Honma 2017; Hudson 2017a; Schlesselman-Taranago 2017). These critiques demonstrate an overwhelming need to contest the structural forces of racial inequity by highlighting persistent challenges realizing core values in areas like culturally reflective and representative library services and collections. Advocacy and scholarly work by librarians of colour has also raised important challenges to institutional narratives that posit equity, diversity, and inclusivity (Chou and Pho, 2018; Hathcock 2015; Hankins and Juarez, 2017; Gonzalez-Smith, Swanson, and Tanaka, 2014; Jackson, Jefferson, and Nosakhere, 2012). At other times, lightning rod social moments have galvanized librarianship and compelled discussion on these often-paradoxical contradictions. One recent example in Canadian librarianship is the collective grappling with the revelations of the trauma and violence experienced by Indigenous communities made public by the Truth and Reconciliation Commission of Canada (2015). The Canadian library community responded with a participatory, action-oriented, and emancipatory self-examination process to scrutinize library work, evaluate current relationships, and advance reconciliation with Canadian Indigenous communities (CFLAFCAB 2017). Five years later, the result has been sustained discussions on settler colonialism and efforts to better understand how decolonization can be undertaken in librarianship.

Another such moment appears to have occurred following the death of George Floyd and the resounding global shockwave of anger that cast light on the foundation of police violence and anti-Black racism that is structurally embedded in contemporary 
society. On May 25, 2020, the world watched in horror as video spread of Floyd, an unarmed Black man, dying during an arrest by Minneapolis Police Department (MPD). The alarming video showed officer Derek Chauvin kneeling on Floyd's neck for 8 minutes and 46 seconds with members of the MPD nearby and community members filming in distress (Hill et al 2020). Floyd's alleged crimes, which led to his suffocation by police in broad daylight on a Minneapolis street, were that he was trying to pass a counterfeit $\$ 20$ bill in a nearby shop and was publicly intoxicated. As video of the arrest began to circulate widely, a new and large wave of Black Lives Matter (BLM) protests grew across the United States, in Canada, and around the world. Whether it was the sheer inhumanity of Floyd's death, the undeniable video evidence of further police violence that bore a striking resemblance to the deaths of other unarmed Black men like Eric Garner and a reported 70 others whose last words were "I can't breathe", or the magnitude of the protests amid the global COVID-19 pandemic, the glaring and enduring racial injustice felt by Black communities worldwide had finally begun to be widely acknowledged (Baker et al 2020).

Black Lives Matter is a decentralized racial justice movement that was sparked in response to the similarly evocative murder of 17-year-old Trayvon Martin and the acquittal of George Zimmerman in 2013 (BLM 2020). Since then, BLM protests have continued unabated in North American cities as anti-Black racism remains a leading cause of harm and trauma to Black communities. Anti-Black racism is defined as a twopart process of devaluing of Black lives through widespread "prejudice, attitudes, beliefs, stereotyping and discrimination" along with systemic marginalization supported by the collective working of societal policies, institutions, and ideologies (Ontario 2017, 67). Cole describes anti-Black racism as a dual process in which "white settlers deny Black communities the necessities of life, then blame [them] for the social dysfunction that follows" (2020, 171-172). As Cole's description suggests, this pronounced societal mistreatment is supported and often exacerbated by interrelated forms of systemic marginalization in which many Black communities lack access to the freedoms and opportunities afforded to others. This results in ever-worsening social and economic conditions that further disadvantage communities through education and employment inequity, reduced access to social services and support, increased surveillance and policing in their communities, and disproportionate incarceration and harsher treatment in the criminal justice system (Cole 2020). The COVID-19 pandemic only worsened existing inequities as the disproportionate impact on racialized groups left many in precarious and unsafe work and home environments with little protection for themselves and their families (Wane 2020).

In the summer of 2020, it appeared that the extraordinary resurgence of BLM protests was met with markedly more public support and participation than in past years. There were protests in major Canadian cities with some having up to as many as 10,000 in attendance (London Free Press 2020). The protests were also supported by Prime Minister Justin Trudeau, who joined in Ottawa, to symbolically, and somewhat ironically as the head of government, kneel in a show of solidarity against state violence to Black communities. The broad outpouring of public support centered around justice and action - and not just from police and criminal justice systems. Rather, there was a distinct rise in anti-racist consciousness as many began to take seriously the demands 
by BLM and others about the epidemic of structural racism. These calls include recognizing anti-Black racism as a public health crisis, addressing systemic marginalization in education, and new policing models that support reconciliation with Black communities (BLM Canada 2020). Prominent individuals, institutions, and organizations responded with a plethora of statements that expressed shock at Floyd's death, support for racial equality and the end of police violence, and often commitments to evaluate how systemic racism had permeated their institutions and practices. Amongst these were large Canadian financial institutions, trade and professional unions, hospitals and hospital foundations, colleges and universities, churches and religious institutions, media, and the non-profit sector.

Research from the United States showed that libraries had taken a fragmentary and sometimes spurious approach to past moments of intense racial justice activism (Gibson et al. 2017; Gibson et al. 2020). The extraordinary reaction to Floyd's death appeared to garner a pronouncedly different response as there was a burst of activity that ranged from statements of support to the more common sharing of anti-racism and Black history reading lists. Others took part in global social media campaigns such as \#BlackOutTuesday in solidarity with BLM protesters and Black communities. A cursory look at the Canada library community-broadly defined as the whole of public, academic, and special libraries, library schools, and professional, provincial, and national library associations-suggests they responded in kind. Like other library institutions around the world, many took to social media and employed resource curation and promotion avenues such as blogs to position themselves as arbiters of information in larger conversations on anti-Black racism. However, this study of 97 institutions in the Canadian library community shows that only $34 \%$ formally responded with a statement and even fewer situated themselves as meaningful contributor to systemic racism. When acknowledged, the role of libraries was predominantly framed as one of information literacy to communities as opposed to participants in a system of white supremacy or cultural normativity. It also found that responses were primarily directed at the non-Black community and crucially failed to address the present and enduring emotional trauma and burden on Black communities. Although often positioned as antiracist and inclusive, this study presents troubling evidence about the ways in which the Canadian library community conceives and responds to profound acts of racism and injustice. This perspective appears antithetical to professional core values and professional practices and one in which the collective failing of the sector to appreciate the dominance of whiteness, redress how it furthers racial injustice, and acknowledge the force of race in the history and contemporary operations of library institutions must be recognized as a powerful act of racism itself.

\section{Conceptualizations of race, racism, and anti-racism in LIS}

Race is both a powerful social force that exacts great damage and a profoundly flawed social construct that has no evidentiary basis. Within the field of LIS, there is a growing and deeply informed body of scholarship that aims to bridge these contradictory positions by theorizing how these problematic conceptions appear in professional work and interactions. In an early and significant work, Honma situates and 
re-examines librarianship in its historical context to explicate the embeddedness of racial oppression in the profession (2005). He draws attention to impactful forms of socio-historical reimagining and erasure that obscure the shift from the dominance of whiteness to perceptions of neutrality. Honma notes that the field eschews "idealized visions of a mythic benevolence" and seeks to frame library history as external to the context of historical and contemporary racial injustice $(2005,2)$. However, he shows that we cannot escape how white culture and knowledge are central to society and institutions that emerge from them $(2005,1)$. In the foreword to Gina SchlesselmanTarango's edited work, Topographies of Whiteness: Mapping Whiteness in Library and Information Science, Honma reminds us that failure to engage with "whiteness and its categorical privileges" is a disservice to those affected and antithetical to social justice, equity, and accessibility (2017, xii). Instead, Honma compels librarianship to reckon with, not turn away from, the replication of racially oppressive knowledge and culture that is tied to the enduring racial order in society (2005).

Espinal (2001) and Espinal, Sutherland, and Roh (2018) locate whiteness and white culture as "social and ideological" concepts to expose the poignant fallacy that whiteness is not racial $(2001,135)$. From this perspective, Espinal notes that race is embodied and as such this renders knowledge similarly embodied (2001, 145). Thus, notions of whiteness and white culture as neutral or objective knowledge are simply untenable $(2001,145)$. Schlesselman-Tarango also examines whiteness in LIS from the perspective of a white woman acknowledging that her work is embedded and informed by this problematic dynamic (2017). Her exploration of Critical Whiteness Studies brings transdisciplinary scholars into dialogue with LIS scholarship to reveal how the field has demarcated itself from existential critiques to our detriment (2017). Alongside Critical Whiteness scholarship in LIS, there is a significant body of literature on the marginalization and erasure of librarians of colour that provides insight into the personal experience of those whose work and lives are undermined in the profession (Cho, Pho and Chu 2018; Hankins and Juarez 2017; Gonzalez-Smith, Swanson, and Tanaka 2014; Jackson, Jefferson, and Nosakhere 2012; VanScoy and Bright 2019). These scholars along with others like Hathcock (2015) and Hudson (2017a; 2017b) draw attention to the ineffectiveness of diversity and inclusivity initiatives to respond to and ameliorate systemic marginalization. Rather, their work aligns with anti-racism scholarship to suggest a need to confront and center race in LIS as the key means to address the organizing force of white cultural and social supremacy.

There is a further chorus of voices in critical library scholarship that problematize specific practices and roles within librarianship and scholarly practice. Hathcock shows that encounters between academic library workers of colour and their colleagues, academic library workers of colour and the institution where they work, and white library workers, and communities of colour are routinely fraught with unequal power relations shaped by white supremacy (2015). Due to the scale and vast opportunities for these power balances to manifest, Brook and Lazzaro (2015), Hathcock and Sendaula (2017) along with Espinal (2001) and Espinal, Sutherland, and Roh (2018) describe the academic library as prolific ground for implicit biases and microaggressions that far too often go unaddressed by colleagues and management. Adler (2017) and 
Olsen (2001) offer critiques on the hierarchical ordering and replication of race and other oppressions through classification and cataloguing. Cooke and Sweeney (2017), Cooke, Sweeney and Noble (2016), and Pawley (2006) trouble the longstanding practice of LIS education institutions privileging practical learning over theoretical and experiential teachings on pertinent social issues such as race and racism that are encountered daily in library work. Finally, Kumasi (2012) and Kumasi and HughesHassell (2017) have contributed extensively on contextually examining how race impacts the needs of racialized youth and their perceptions of school and public libraries.

\section{Research study}

Using mixed-method content analysis, the principal goals of this research study were to (a) identify formal responses to BLM protests; (b) analyze themes across how the Canadian library community views and situates itself within conversations of racial justice; and, adjacently, (c) identify the scope of commitments made for future accountability and research. This study appears to be the first to generate robust data on the response of the Canadian library community to the BLM social movement in Canada. It is hoped that it can also be used in future studies to evaluate the responses to subsequent mass social and racial justice movements.

\section{Mixed-method content analysis}

Mixed-method research is an approach to data collection, analysis, and reporting that employs both quantitative and qualitative methods to create a more fulsome and rich understanding of the phenomenon being studied (Williams and Vogt 2011). This study employed a convergent mixed-method design in which quantitative and qualitative data was analyzed independently and then merged to inform the results (Creswell and Plano Clark 2011). Within a mixed-method methodology, content analysis often entails a systematic search and review of text to identify shared characteristics, determine their frequency, and draw inferences about identified trends and themes (Creswell and Plano Clark 2011). In this study, it was employed as a quantitative technique to measure the number of organizations that issued statements, the prevalence of identified characteristics, and to count words and phrases. Whereas reflexive thematic analysis was used to qualitatively describe patterns identified in the data and the potential effects.

Thematic analysis is a comparative approach to continuous engagement and reflection to analyze themes, perspectives, and occurrence of ideas and their meanings. Virginia Braun and Victoria Clarke refined the approach as reflexive thematic analysis to distinguish it from similar qualitative thematic analytic methods (e.g., narrative analysis, grounded theory, phenomenological analysis, etc.) $(2006,78)$. Braun and Clarke note that reflexive thematic analysis is especially useful in instances where the researcher seeks "to [both] reflect reality and unpick or unravel the surface of reality" $(2006,81)$. In contrast to positivist approaches that posit an objective or neutral relationship between the researcher and results, reflexive thematic analysis acknowledges the 
conscious participation of the researcher in selecting, describing, and reporting data (Braun and Clarke 2006, 80). Thus, reflexive thematic analysis compels explicit recognition and reflection on the epistemological and theoretical "positions and values" of the researcher and their application to the study (Braun and Clarke 2006, 80).

\section{Theoretical and epistemological framework}

This study was guided by the framework for anti-oppression research designed by Canadian anti-oppression researchers Karen Potts and Leslie Brown (2005). The foundational premise is that social justice research-defined as research that aims to foster greater equity, access to power and resources, and participation-is not inherently anti-oppressive $(2005,25)$. In fact, it can often reinforce oppression through the perpetuation of epistemic knowledge and power relationships $(2005,35)$. Potts and Brown identify three guiding conditions of anti-oppression research. Firstly, that it is concerned with problematizing outcomes and processes of social justice research as opposed to only addressing the causal effects (Potts and Brown 2005). This is operationalized through the object of the study and includes a rejection of dominant research methodologies that aim to study and/or speak for others. Anti-oppression frameworks are focused on "reversing the gaze" onto the oppressive processes and relations of power that underlie systems of inequality (Potts and Brown 2005, 19). Secondly, the research must account for the social and political construction of knowledge and situate research in the context that it emerges (Potts and Brown 2005). "Truth is created", according to Potts and Brown (2005, 20). Thus, it adopts a social constructivist approach to seeking to understand the epistemological foundations of knowledge rather than seeking to validate its truthfulness (Potts and Brown 2005). Finally, anti-oppressive research is based on an understanding that relationships to and in research are not unproblematic. Researchers, regardless of methodological approach, carry individual beliefs, interpretations about the world, and biases that must be acknowledged in the research process (Potts and Brown 2005). Consequently, there must be reflexive and continuous scrutiny to identify, account for, and correct the unequal relations of power.

Critical race theory (CRT) is also pertinent to this study because its core premise is that race is a central social organizing principle of society and that the impacts of racism must be an essential component of analyses that examine contemporary society (Delgado and Jean Stefancic 2013). Critical LIS scholarship has noted a tendency within the field to use unproblematized ideas and positions such as race neutrality and objectivity in library work (Caidi, Ghaddar, and Allard 2017; Gibson et al. 2017; Gibson et al. 2020; Gohr 2017; Honma 2005; Hudson 2017a; Hudson 2017b; Schmidt 2019; Schlesselman-Tarango 2017). Thus, CRT is a useful tool to trouble popular, albeit faulty, disciplinary norms, concepts, and assumptions that are often frequently invoked to posit the absence or irrelevance of race in library practice. Methodologically, CRT analyses are also incredibly useful to reveal how organizational narratives work to suppress the identification and exposure of structural racism. Now in its fifth decade of scholarship, CRT has faced criticism for its lack of tangible progress towards societal and institutional reform (Dixson and Rousseau 2005; Howard and Navarro 2016). Nevertheless, CRT is 
only a theoretical departure point and social and institutional change is dependent on a commitment to address the underlying social structural factors that CRT analyses bring to light.

Finally, this work adopts an anti-racist framework that is informed by the work of Ghanian-born Canadian scholar George Sefa Dei (2014) and critical theorist Sara Ahmed. Dei's highly influential scholarship focuses on disrupting "pathologizing discourses" that respond to the causal effects of racial oppression as opposed to the institutional and social practices that allow them to perpetuate $(2014,25)$. Dei's work is also useful because of its sensitivity to the simplistic idea that systemic racism is the result of nefarious or deliberate intent. As an educator and education scholar, Dei is mindful of well-meaning intentions behind the work of people in social service professions $(2014,14)$. However, he stresses the need to disrupt the normative acceptance of white Eurocentrism as neutral and objective knowledge. Rather, he calls attention to the discursive work of white Eurocentrism to both produce "hegemonic knowledges" and reproduce hegemonic structures of power (Dei 2014, 18). Further, Dei calls for the cultivation of humility, which he describes as an understanding that systemic racism does exist and that we take part in it regardless of whether we are active or willing participants (Dei 2014). To that end, anti-racism is not an attack on people or their professional work. For Dei, it is a repudiation of systemic oppression and a call to "rehumanize research and policy" in keeping with professional and personal values $(2014,17)$.

Ahmed offers a more pointed critique of institutional narratives and their claims to anti-racism (2004, para 1). Drawing attention to the profound difference between stating an anti-racist perspective and enacting anti-racism practices, Ahmed is deeply suspicious of admissions of structural oppression and commitments found in "institutional speech acts" (2004, para. 1). She is particularly concerned with the positional leap that often occurs such that recognition of institutional racism becomes a signpost of being anti-racist (2004, para. 7). While institutional commitments are noteworthy because they reveal an awareness of the need to reflect qualities such as anti-racism (2004, para. 1), they are essentially non-performative because they "work by not bringing up the effects that they name" and are impossible to actualize in the institutional structure that they are situated within because they lack a redistribution of power (2004, para. 3).

\section{Researcher subjectivity and motivation}

As these theoretical frameworks suggest, it is important to acknowledge that the researcher of this study is a white woman who enjoys earned and unearned privileges such as being Canadian-born, English speaking, formally educated, and middle-class. It is also crucial to be clear that the intent of this study is not to speak for or on behalf of Canadian Black communities. Recalling Potts and Brown who note that "most research is organized with a gaze facing the wrong way, toward those who suffer from inequities rather than those who benefit from them or are indifferent", the Canadian library community is the explicit object of this study $(2005,24)$. This focus is further informed by longstanding challenges in the sector to meet institutional commitments to better 
reflect core values such as equity, diversity, and inclusion. Poignantly described as being "paralyzed by whiteness" (Galvan 2015, para. 3), the potential impact of racial bias and complacency in librarianship is profound with a reported $87 \%$ of the workforce identifying as white (Schmidt 2019). Consequently, it is important for white members of the library community to actively engage in racial justice work to ameliorate bias and the burden that is most often unfairly placed on members of racialized groups to address systemic inequity.

\section{Study sample}

Ninety-seven organizations were selected for participation in the study. Stratified purposive sampling was used to select organizations that represent a cross-section of the different types of library organizations in Canada and those that serve a significant number of the population. Further, due to the researcher's primary language for reading and comprehension, the sample includes organizations that provide public communications in English. French language organizations were included when public communications were also made available in English.

\section{Sample selection criteria}

Organizations were selected and classed as follows: 13 were national or provincial library associations, eight were professional or library-specific associations (e.g., public, academic, and special library), 44 were public libraries, 24 were academic or research libraries, and seven were faculties or departments at Canadian universities with a master's level program in library and/or information science. The following criteria was used to select and classify participants:

a. National or provincial/territorial library associations

All Canadian national and provincial/territorial library associations were included in the study sample. One was national (8\%) and 12 were provincial/territorial (92\%) associations.

b. Professional or library-specific associations

Of the eight organizations selected, two were professional associations that operate nationally and whose members are librarians or information professionals $(25 \%)$, five were national associations whose members are library-specific organizations $(62.5 \%)$, and one was a national organization for library and information science scholars and practitioners (12.5\%). Provincial associations that represented a specific sector of library service (e.g., Federation of Ontario Public Libraries) were eliminated due to the discontinuity in terms of provinces represented, online presence, and indications of being operational during the COVID-19 pandemic.

c. Public library organizations

Public library organizations were selected based on membership in the Canadian Urban Library Council (CULC) and represent libraries in urban areas with populations 
over 100,000. CULC member organizations were selected as they serve three-quarters of the Canadian population and they account for $80 \%$ of activities undertaken by Canadian public libraries (CULC 2021).

\section{d. Academic/Research library organizations}

Academic and research library organizations were selected based on membership in the Canadian Association of Research Libraries (CARL) and represent the largest Canadian research libraries in terms of library staff (librarians/library personnel) and research activities (CARL 2019). Two were federal government libraries (7\%) and 25 were university libraries (93\%). Libraries of affiliated campuses, colleges, or research institutes were not included in the study.

\section{e. Faculties or departments at Canadian universities}

All English-speaking faculties or departments at Canadian universities with a program related directly to the study of library and/or information science were included in the study.

\section{Data collection}

Formal statements issued that addressed anti-racism or anti-Black racism in response to Floyd's death and/or BLM protests were collected for analysis. Statements were collected between May 25, 2020, and August 1, 2020. Most statements were issued during the first three weeks of the sample period (up to June 19, 2020). However, several statements were made up to two months after Floyd's death and were also included in the study. Statements were collected from the organization website under variously named sections for communicating public information (e.g., News, Current Events, Press Releases, Blogs, etc.). Social media pages were also crossreferenced to identify if formal institutional statements were posted there as opposed to on the institutional website.

\section{Data coding}

This study adopted a primarily inductive coding method that was conducted using NVivo 12 to assist in the management and analysis of the data. It was anticipated and confirmed that specific themes and wording would be found in statements (e.g., Black Lives Matter, condemnation of racism, commitments to anti-racism, etc.). However, a formal codebook was not developed a priori to capture nuance and variance in stated intent and meaning. The statements were first critically reviewed by the researcher and inductive codes were applied on the second and third readings. Following this, the researcher reviewed the codes derived from the data, identified broad themes, and referred to the original text to ensure that the selected theme/s best represented the portion of the statement. The themes identified were readily apparent to the researcher and verified by text searches, quantitative data options in NVivo (i.e., number of times specific words mentioned), and information visualization options. 


\section{Limitations}

While the study includes many leading library organizations in Canada, it is not an exhaustive list of organizations that may have issued a statement at the time. Many organizations also had significant activity on social media that was collected and crossreferenced for accuracy. As the study objective was to analyze formal responses that were attributable to individuals (e.g., Library Director) or governing bodies (e.g., Board of Directors) able to speak authoritatively on institutional perspectives, non-official commentary through staff blogs, social media posts, and book lists that were not a part of the formal statement were not included in the analysis.

\section{Results}

Of the 97 members the Canadian library community sampled, 34\% (33 organizations) made a formal statement that addressed anti-racism and supporting Black communities. While this does anecdotally appear to be meagre given the scale of events, it is not within the scope of this study to speculate on organizational decisions to not issue a statement. There is also limited data available to compare to other similar moments of rising social consciousness in Canadian society. Thus, it is not possible to comment on how this response compares to other social service sectors or past responses to social justice movements within the sector.

\section{Statements issued}

Institutions that did issue a formal statement varied substantially by category (Table 1 provides a full breakdown). For example, 57\% of faculties or departments with programs that offer a master's degree in library and/or information science did issue a statement. Only $7 \%$ of academic and research libraries issued a formal statement that detailed specific library commitments or responses. These statements were from academic libraries at Canadian research universities whereas no federal government libraries offered official commentary during the sample period. Of the 25 academic libraries sampled from a Canadian research university, 23 (92\%) of their respective institutions did issue a public statement. Fifteen academic libraries $(65 \%)$ shared these statements via one or more social media account or in resource recommendations by academic libraries. However, it is important to note that these larger institutional statements also expressed strong pledges to address systemic racism campus-wide and made commitments to further respond across their university community.

Professional and/or library-specific associations responded significantly higher than the average found in the study sample. However, there was a large variation in the scope and content of these statements. Two associations (40\%) issued statements that consisted of one to two sentences that expressed support for those engaging in BLM protests, stated their commitment to other policies, and/or broadly condemned racism. While these qualified for inclusion in the study, their brevity and vagueness must be emphasized. In addition, one library-specific organization reissued a statement and nonbinding policy that was drafted and approved by its members and parent organization in 2017. This also met the requirement for study inclusion as it was re-issued during the 
study period, but it offered no new commentary that addressed Floyd's death, BLM or anti-Black racism directly. The affiliated parent organization did issue a statement that addressed the BLM movement directly and identified the role of libraries to work towards "dismantling systemic racism" as an addendum to the 2017 policy on race and equity. However, the addendum was not shared or noted by the Canadian libraryspecific organization. This 2017 statement was also referred to by 11 other institutions that issued a statement as either evidence of their existing commitment to anti-racism or in one instance as an "aspirational goal". None shared or referenced the more current addendum.

\begin{tabular}{|l|c|c|c|}
\hline \multicolumn{1}{|c|}{ Organization Category } & In study & Statements & $\mathbf{\%}$ \\
\hline National or provincial library associations & 13 & 5 & $38 \%$ \\
\hline Professional and/or library-specific associations & 6 & 5 & $83 \%$ \\
\hline Public Library Systems & 44 & 17 & $39 \%$ \\
\hline Academic Libraries & 27 & 2 & $7 \%$ \\
\hline Library faculties or departments & 7 & 4 & $57 \%$ \\
\hline Total & 97 & 33 & $34 \%$ \\
\hline
\end{tabular}

Table 1: Formal statements by organization category

\section{Reference to other policies and statements}

There was a strong tendency to refer to other policies, statements or strategic plan documents to demonstrate existing organizational commitments or to provide evidence that this work is taken seriously by the organization. Referenced documents were both internal and external to the organization and included organizational mission statements (73\%), position and/or policy statements from affiliated associations (36\%), and organizational strategic plans (15\%). Statements also made a multitude of references to commonly accepted core library values that included descriptions of organizational commitments to diversity and inclusivity (64\%), equitable access for the community (48\%), and libraries as safe spaces (39\%).

\section{Language and content}

Given the scale of events that led to the rise of BLM protests at the time, it is unsurprising that most included explicit condemnation of police violence against Black communities. Yet only six statements referred to Floyd explicitly or listed the names of others whose lives had been lost to police and other forms of racial violence. Only four statements included the names of racialized or Indigenous Canadians that were slain in interactions with Canadian police. Rather, the vast majority used less direct or explicit language about Floyd's death and the resulting protests by using descriptors such as "recent events in the United States and Canada." This lack of direct response or specificity was repeated in other areas as many statements did not explicitly situate library work within societal systems of racial injustice, bias, and oppression. For example, 30 statements (91\%) referenced anti-black racism and 28 statements (85\%) referenced Black Lives Matter, whereas white supremacy was only discussed in 10 statements (30\%) and only three addressed white privilege (9\%). Diversity and 
derivatives of inclusion were referenced over 100 times, while there were no references to terms like social exclusion or marginalization that underpin the need for these kinds of measures in libraries.

\section{Performative and action-based commitments}

The statements widely envisioned their respective organizations playing a substantive role in community-based work to support anti-racism and race equity. However, they often used language consistent with performative anti-racism in which rhetorical support is offered in place of tangible measures to address internal roles, practices, or policies that contribute to systemic racism. This was commonly expressed through figurative descriptions of standing in support or solidarity with members of Black communities and BLM protestors (25 references), condemnations of systemic racism and police violence (21 references) or promises to take "concrete" steps or measures to address systemic inequity (16 references). In some cases, the statements featured commitments that were vague and lacked clear meaning. For example, one library states that "we will strive to replace ignorance with knowledge, intolerance with compassion, and inequity with justice within our community" and another similarly states they are "actively working to promote knowledge over ignorance, understanding over intolerance and access over inequity." Statements also featured broad commitments such as "[keeping] social justice and the real possibility for social change at the core" or being "committed to fostering inclusivity within the larger fight against systemic racism." While these statements reflected language that implied strong support of racial justice and social equity, they tended to not include actions or commitments that would enable measurement or future accountability.

When acknowledged, the role of the Canadian library community was predominantly framed as one of information sharing and community engagement as opposed to offering direct support and/or acknowledgement of white supremacy or cultural normativity. Table 2 provides a fulsome breakdown of commitments made in the 33 statements. Most notably, 12 statements made no commitments or identified any actions that the organization would undertake. The remaining 21 statements featured a wide variety of commitments to review institutional practices to ensure that their operations better reflected principles of anti-racism and social justice. These included promises to review policies and procedures, conduct internal audits, and include antiracism as a facet of strategic planning processes including one commitment to make anti-black racism the theme of 2020 staff training. A lack of diverse representation in the workforce was noted to a lesser extent. Commitments in this area included pledges to better reflect their communities through hiring and in volunteer roles such as on boards and committees. Interestingly, these were typically made by institutions that were not public-facing (i.e. provincial and professional associations), and their plans focused on the development of new policies or engagement opportunities to guide future action. Institutions that were public-facing more heavily favoured plans that included staff training and professional development as areas for further action. The general sentiment was that this was a learning opportunity and that they were 
committed to providing better training and support to individuals on understanding and responding to incidents of racial injustice.

\begin{tabular}{|l|c|}
\hline \multicolumn{1}{|c|}{ Action or Commitment } & Total \\
\hline Statement offered no action or commitment & 12 \\
\hline $\begin{array}{l}\text { Review collections, programming, and policies to promote inclusivity and } \\
\text { equity }\end{array}$ & 8 \\
\hline Staff education and development on systemic racism & 8 \\
\hline Undertake consultations with Black communities, staff, faculty, or members & 5 \\
\hline Acquire, promote, and support awareness of diverse and/or BIPOC resources & 5 \\
\hline $\begin{array}{l}\text { Support initiatives and conversations on systemic racism and/or anti-Black } \\
\text { racism }\end{array}$ & 5 \\
\hline Share anti-racism resources with library community & 4 \\
\hline $\begin{array}{l}\text { Review and incorporate external policies on race, equity, diversity and/or } \\
\text { inclusion }\end{array}$ & 4 \\
\hline Increase participation of underrepresented members, staff, and/or faculty & 4 \\
\hline Eliminate barriers to library programs, services, policies and practices & 3 \\
\hline Develop strategy or policy on diversity and inclusion and/or anti-racism & 3 \\
\hline Develop, review, and/or revise curriculum to include systemic racism & 3 \\
\hline Support Black colleagues, students, and/or staff & 2 \\
\hline Challenge classifications and subject headings & 1 \\
\hline Create anti-Black racism working group & 1 \\
\hline Review membership in affiliated organizations & 1 \\
\hline Confront and resist problematic narratives and language & 1 \\
\hline Establish bursary for BIPOC student & 1 \\
\hline Recommend members revisit policies & 1 \\
\hline Create mechanism for voluntary self-declaration of BIPOC members & 1 \\
\hline Formalize an inclusive and equitable hiring policy & 1 \\
\hline
\end{tabular}

Table 2: Action-based commitments

\section{Information sharing}

Given their role in communities, it is expected that many institutions shared library resources and/or scholarly and professional resources to inform and facilitate discussions on anti-racism occurring in their communities and on social media. These resources most often took the form of curated book lists featuring popular anti-racist authors like Desmond Cole, Ibram X. Kendi, and Robyn Maynard. Many also featured other multimodal resources like documentary films and talks on historical and contemporary racial justice movements, information on other community organizations, and resources for discussing race with children. While the statements often offered impassioned expressions of support for communities that experience racial injustice, this was generally not reflected in the resources or support provided. For example, the resources provided were overwhelmingly directed at the non-Black community and focused on informing and educating about racial injustice to those who do not experience racism, oppression, and bias. This was also expressed in statements such as 
"a critical role of the library is to help people find the resources they need to better educate themselves on topics like racism, racial violence and the struggle for equity" or "reading, listening and learning allows us to better understand the issues at stake and why making this systemic change is so important." Only one organization offered information on emotional and community support for those affected.

\section{Community engagement}

There were frequent indications that library institutions had aspirational goals to engage in more fruitful and meaningful conversations with their communities about racial equity and justice. However, these commitments were often vague and offered intangible specifics on who they envisioned as participants in the conversations, timelines for execution, or a framework for moving forward with measurable actions. In cases where there were commitments made to better listen or respond to Black communities, they offered few strategies to support this work. In fact, only one public library organization identified forming an anti-racist working group to foster the type of engagement that the institutions were committing to undertake. Rather, commitments focused on better community engagement as an institutional goal in terms of helping facilitate conversations to aid others to better understand racism. More problematically, there were also limited indications of meaningful roles for the Black community and they were often framed as a homogenous group whose interests or needs were solely addressing racial injustice. For example, one statement identified "reaching and engaging disenfranchised people in the community and helping them express their voice" while another statement noted that "no rewarding conversation can exist without genuine understanding and true compassion." There were only five commitments to improve consultation and reflection with Black communities in their work (i.e., staff, volunteer members, library collections, or programs and services). There were also no commitments to ensure these conversations were led by members of Black communities. Rather, the spirit of commitments to fostering greater community engagement was that they wanted to listen and support anti-racism in their communities as opposed to explicitly engaging with anti-racism as a practice themselves.

\section{Discussion}

As the epigraph poignantly highlights, racial oppression and its impacts cannot be addressed when the Canadian library community turns away from its collective culpability to address the oppression built into society and its institutions. Responding to police violence and the impacts of systemic bias in criminal justice and health care are important first steps. They are exactly that, though-first steps. There remains larger and far deeper work to be done across all sectors of Canadian society to undo the four centuries of marginalization that have left Black communities widely disadvantaged in health and wellbeing, safety and basic needs, life opportunities, and access to culturally relevant and appropriate services. While most visible through the lens of police violence or disproportionate health outcomes, policing and healthcare inequities are not 
aberrations in an otherwise racially just society. Anti-Black racism permeates all parts of society and is supported by the collective working of social structures across Canada. Like libraries and higher education, police, criminal justice, and healthcare are a part of a system of structural racism and oppression that is a scourge in our society. This depth of structural embeddedness also demonstrates that it is ineffective to address this problem in piecemeal or within sectors individually. Rather, a crisis of this magnitude requires a pan-Canadian solution that includes measures to not only educate Canadians, but to actively work collectively with Black communities to effectively reduce racial inequity at the structural level.

Race in Canada is a complex social phenomenon that is profoundly linked to our colonial past. In recent years, there has been significant attention paid to the legacy of the relationship between Indigenous communities and Canada. This includes acknowledging that Canada is a settler state that was formed through processes of colonization and racism. However, Canadian anti-racism scholars also underscore that our colonial history is intrinsically tied to widespread anti-Blackness and the exploitation of Black communities (Cole 2020). Thus, we must also work to address the antiBlackness that anchors white normativity and the tacit perpetuation of white supremacy in Canada. Librarianship, like all parts of society, has a role to play in this national reckoning that must be more substantive than providing information and expressing our support for those who suffer the ill effects of racial injustice. Anti-racism is not an aspirational goal, social media campaign, or buzzword that can be invoked to demonstrate an institutional response to inequitable societal relations elsewhere. It is a practice of decentering white supremacy and rebuilding equitable relationships to end racial injustice. In other words, simply declaring that "we are anti-racist" is not the end of the work when systems of structural inequity that cause immeasurable harm have been left firmly in place. These statements ought to be the beginning of a larger, protracted, and more difficult process of evaluating and restructuring librarianship in a way that works to meaningfully dismantle racism in all its forms.

Libraries across Canada reported being inundated with requests for resources on anti-racism in the wake of the 2020 BLM protests. This demonstrates that libraries are a largely trusted social organization. It also shows the vast structural, material, and social power of libraries to shape community conversations and resources on racial justice. This community trust behooves libraries to recognize and acknowledge the scale of racial oppression in the country. A recent national study found that two-thirds of Canadians believe that the country fares better in its treatment of racialized groups than the United States (Canadian Race Relations Foundation and Environics Institute 2019, 4). Yet, this perspective was easily troubled when three non-White Canadians died during police interactions in the month of June 2020 alone. Chantel Moore, a member of Tla-o-qui-aht First Nation, was shot during a wellness check by police in New Brunswick; Rodney Levi, a Mi'kmaq man, also shot by New Brunswick police during a routine interaction; and, Ejaz Ahmed Choudry, a Canadian Muslim man with known mental health issues was shot in Peel Region after his family called for a non-emergency wellness check (CBC 2020). Further questions also continue to be raised about the death of Regis Korchinski-Paquet, a 29-year-old Indigenous-Ukrainian-Black Canadian 
woman, who fell from her Toronto balcony in May 2020 also during a police wellness check (Mendelsohn Aviv 2020). Thus, while it is laudable that the Canadian library community quickly responded to Floyd's death, there are equally disturbing questions that must be asked here in Canada too.

This is not to suggest that the sector should not devote resources and effort into curating book lists, sharing content, and providing access to resources to better understand white supremacy. It is to underscore that this is an inflection moment in which the Canadian library community must critically look at its role in supporting an unjust society and better understand how our profession responds to racial justice and inequity in communities. Recalling that a key facet of movements for racial justice such as BLM is to make clear the linkages between white supremacy, privilege, and anti-black racism, it is disconcerting that there were scant efforts to provide substantive and measurable responses to the needs of Canadian Black communities as they witnessed enormous trauma. It is further troubling that so few library institutions articulated a central role for Canadian Black communities amidst claims to supporting anti-Black racism as an organizational practice. Concisely demonstrating Espinal, Sutherland, and Roh's point that a key problem of whiteness is how it "fosters homogenous attitudes and processes" that do not feel harmful to those with decision-making power and blinds them from identifying their role perpetuating structural problems $(2018,148)$. It is highly doubtful that is a conscious decision to underserve Black communities or ignore their needs. Rather, it demonstrates the Ontario Government's point that anti-Black racism has become "so functionally normalized or rendered invisible to the white population" that it is unremarkable to ignore and systematically exclude Black experiences and perspectives $(2017,67)$.

To this end, it is also helpful to keep in mind Cole's sage insight that "white supremacy, which informs and fuels anti-Black racism...is never personal, never individual, never isolated" $(2020,7)$. In other words, anti-Black racism is not an exercise in leveling guilt or blame. It is a practice and methodology that anchors library work in principles of equity and justice to redress historical imbalances and injustice. This is highly introspective work that is done internally to evaluate processes and practices that are contributing to societal oppression, examining how we as institutions and individuals benefit from white supremacy, and the ways it enters our spaces. It is also a reconciliatory and justice minded method that is focused on an expressed commitment to move past approaches found within institutions in which the result is a model of community engagement that strives to ameliorate, rather than mask, the effects of racial inequity. There is a persistent hesitancy to acknowledge anti-Black racism as a form of structural privilege and address its impacts on Black communities in Canadian librarianship. Thus, it is helpful to note that anti-Black racism has been identified by multiple levels of government as prolific across all Canadian social and cultural institutions (Alberta 2018; Heritage Canada 2019; Ontario 2017). In fact, it is so widespread that they have specifically asked social service institutions to undertake the work of understanding how systemic racism functions in their fields and address it (Alberta 2018; Heritage Canada 2019; Ontario 2017). While this shift in policy acknowledges that institutions engage in practices that negatively impact the lives and 
well-being of Black communities, they also underscore that they are not purposefully racist. Like practices of decolonization, anti-racist work is a participatory, actionoriented, and emancipatory process that is rooted in the needs of those most affected (Lipsitz 2019). As a practice and methodology, anti-racism compels a wholly collaborative approach to creating culturally representative and inclusive communities and spaces. Recalling Dei's view that anti-racism is a practice in humility for those beholding both cultural and institutional power, this also means listening to uncomfortable accounts and experiences of racial oppression in institutional spaces as well as being willing to implement corrective measures to address misaligned practices that reinforce white supremacy. As a starting point, this means adopting a conscious and deliberate commitment to hold institutions accountable to the promises made in both mission statements and those in the wake of profound injustice.

\section{Conclusion}

While the Canadian library community cannot right Floyd's death, it can do its part to undertake strategic action that serves to break systemic processes of oppression. The deep internal work that anti-racism begs ought not to feel daunting to the Canadian library community. In fact, it has demonstrated significant resources and capacity to take on this kind of change through the Canadian Federation of Library Associations (CFLA-FACB) led process of truth and reconciliation. Throughout this process, the Canadian library community worked together within the exact kind of participatory, action-oriented, and emancipatory framework that anti-racist work compels to examine their relationship and advance reconciliation with Canadian Indigenous communities. The resulting CFLA-FCAB Truth and Reconciliation Report and Recommendations (2017) further provided many of the same outcomes that anti-racist approaches to service and administration require: promotion and development of inclusive services, removal of barriers to participation, and addressing the roots of systemic racism that manifest in organizational practices. In other words, the Canadian library community is well-positioned to undertake the process of becoming anti-racist. Moreover, commitments to addressing anti-Black racism are really a furthering of the commitments made then and now to align librarianship with its core values. Whereas diversity and inclusion narratives shift focus and responsibility from the institutional to the individual level, anti-racism draws attention to historical inequity, rejects the notion that libraries are neutral, and aims to realign and reconstruct policies and institutions in accordance with principles of racial justice. Which is to say, there is a profound difference between performing anti-racist work and doing anti-racist work. As we look to the future, the Canadian library community can no longer perform anti-racism-they must actually be anti-racist institutions that reflect and demonstrate a commitment to all communities served. 


\section{Acknowledgements}

I would like to acknowledge Drs. Heather Hill and Paulette Rothbauer for their guidance and support while developing this research project. I also extend my sincere appreciation to David S. Size and Connor Spearman for their contributions to the editing and revision stages.

\section{About the Author}

Amber Mathews is a Library and Information Science (LIS) doctoral student at Western University and a Joseph-Armand Bombardier Canada Graduate Scholarship holder. Her research examines systemic racism in public libraries and its impacts on racialized youth in Canada. Her doctoral research project is grounded in anti-oppression methodologies, specifically anti-racism, and suggests that failing to account for race and redress systemic power relationships denies historical imbalances of power and entrenches systemic racism. Professionally, Amber also coordinates literacy and learning programs at the community level for vulnerable youth experiencing multiple and intersecting forms of social marginalization in London, Ontario. Her research is supported in part by funding from the Social Sciences and Humanities Research Council.

\section{References}

Adler, Melissa. 2017. "Classification Along the Color Line: Excavating Racism in the Stacks." Journal of Critical Library and Information Studies 1 (1). https://doi.org/10.24242/jclis.v1i1.17.

Ahmed, Sara. 2004. "Declarations of Whiteness: The Non-Performativity of AntiRacism." Borderlands 5 (3).

Baker, Mike, Jennifer Valentino-DeVries, Manny Fernandez, and Michael LaForgia. 2020.

"Three Words. 70 Cases. The Tragic History of 'I Can't Breathe'." New York Times, June 29, 2020. https://www.nytimes.com/interactive/2020/06/28/us/icant-breathe-police-arrest.html

Black Lives Matter. 2020. "About Black Lives Matter". Black Lives Matter. https://blacklivesmatter.com/about/

Black Lives Matter Canada. 2020. "Defund the Police - Demands." Black Lives Matter Canada. https://web.archive.org/web/20210131030447/ https://blacklivesmatter.ca/defund-the-police/.

Brook, Freeda, Dave Ellenwood, and Althea Eannace Lazzaro. 2015. "In Pursuit of Antiracist Social Justice: Denaturalizing Whiteness in the Academic Library." Library Trends 64 (2): 246-84. https://doi.org/10.1353/lib.2015.0048.

Braun, Virginia and Victoria Clarke. 2006. "Using Thematic Analysis in Psychology" Qualitative Research in Psychology 3: 77-101. https://doi.org/10.1191/1478088706qp063oa.

Caidi, Nadia, J. J. Ghaddar, and Danielle Allard. 2017. "Negotiating borders: librarianship and twenty-first-century politics." The Library Quarterly 87 (4): 391-409. 
Canadian Broadcasting Corporation. 2020. "2020 already a particularly deadly year for people killed in police encounters, CBC research shows." Canadian Broadcasting Corporation, July 24, 2020.

https://newsinteractives.cbc.ca/fatalpoliceencounters/\#: :text=There\%20were \%2030\%20people\%20killed,by\%20the\%20CBC's\%20own\%20researchers.

Canadian Federation of Library Associations [CFLA-FCAB]. 2017. Truth and

Reconciliation Report and Recommendations. http://cfla-

fcab.ca/en/indigenous/trc_report/

Canadian Race Relations Foundation and Environics Institute. 2020. Race Relations in

Canada 2019 Survey. Canadian Race Relations Foundation.

https://www.environicsinstitute.org/docs/default-source/project-documents/race-

relations-2019-survey/race-relations-in-canada-2019-survey---final-report-

english.pdf?sfvrsn=ef8d61e3_2.

Canadian Urban Library Council. 2020. Statement on Race and Social Equity.

http://culc.ca/advocacy/statements-briefs/statement-on-race-social-equity/

Chou, Rose L., Annie Pho, and Clara M. Chu. 2018. Pushing the Margins: Women of Color and Intersectionality in LIS. Edited by Rose L. Chou and Annie Pho.

Sacramento, CA: Library Juice Press.

Cole, Desmond. 2020. The Skin We're In: A Year of Black Resistance and Power.

Toronto: Doubleday Canada.

Cooke, Nicole A., and Miriam E. Sweeney. 2017. Teaching for Justice: Implementing Social Justice in the LIS Classroom. Edited by Nicole A. Cooke and Miriam E. Sweeney. Sacramento, CA: Library Juice Press.

Cooke, Nicole A., Miriam E. Sweeney, M., and Safiya U. Noble. 2016. "Social Justice as

Topic and Tool: An Attempt to Transform a LIS Curriculum and Culture." Library Quarterly 86 (1): 107-124. https://doi.org/10.1086/684147.

Creswell, John W., and Vicki L. Plano Clark. 2011. Designing and Conducting Mixed Methods Research. Los Angeles: SAGE Publications.

Dei, George J. S. 2014. "A Prism of Educational Research and Policy: Anti-Racism and Multiplex Oppressions." In Politics of Anti-Racism Education: In Search of Strategies for Transformative Learning, edited by George J.Sefa Dei and Mairi McDermott, First, 15-28. Dordrecht: Springer Netherlands.

Delgado, Richard, and Jean Stefancic. 2013. Critical Race Theory: The Cutting Edge. Edited by Richard Delgado and Jean Stefancic. Third. Philadelphia: Temple University Press.

Dixson, Adrienne D, and Celia K Rousseau. 2005. "And We Are Still Not Saved: Critical Race Theory in Education Ten Years Later." Race, Ethnicity and Education 8 (1): 7-27. https://doi.org/10.1080/1361332052000340971.

Espinal, Isabel. 2001. "A New Vocabulary for Inclusive Librarianship: Applying Whiteness Theory to Our Profession." In The Power of Language / El Poder de La Palabra; Selected Papers from the Second REFORMA National Conference, edited by Lillian Castillo-Speed, 131-49. Englewood, Colo: Libraries Unlimited.

Espinal, Isabel, Tonia Sutherland, and Charlotte Roh. 2018. "A Holistic Approach for 
Inclusive Librarianship: Decentering Whiteness in Our Profession." Library Trends 67 (1): 147-62. https://doi.org/10.1353/lib.2018.0030

Galvan, Angela. 2015. "Soliciting Performance, Hiding Bias: Whiteness and Librarianship." In the Library with the Lead Pipe.

http://www.inthelibrarywiththeleadpipe.org/2015/soliciting-performance-hidingbias-whiteness-and-librarianship/

Gibson, Amelia N., Renate L. Chancellor, Nicole A. Cooke, Sarah Park Dahlen, Shari A. Lee, and Yasmeen Shoris. 2017. "Libraries on the Frontlines: Neutrality and Social Justice." Libraries 99. https://doi.org/10.1108/EDI-11-2016-0100.

Gibson, Amelia N., Renate L. Chancellor, Nicole A. Cooke, Sarah Park Dahlen, Shari A. Lee, and Yasmeen Shoris. 2020. "Struggling to Breathe: Covid-19, Protest, and the LIS Response." Emerald 40 (1): 74-82. https://doi.org/10.17615/yhe2-8w37.

Gohr, Michelle. 2017. "Ethnic and Racial Diversity in Libraries: How White Allies Can Support Arguments for Decolonization." Journal of Radical Librarianship 3: 42-58. Gonzalez-Smith, Isabel, Juleah Swanson, and Azusa Tanaka. 2014. "Unpacking Identity: Racial, Ethnic, and Professional Identity and Academic Librarians of Color." In The Librarian Stereotype: Deconstructing Perceptions and Presentations of Information Work, edited by Nicole Pagowsky and Miriam Rigby, 149-73. Chicago: Association of College and Research Libraries.

Government of Alberta. 2018. Taking Action Against Racism: What Albertans Told Us and What to Do Next.

https://open.alberta.ca/publications/taking-action-against-racism\#summary Government of Ontario. 2017. A Better Way Forward: Ontario's 3-year Anti-Racism Strategic Plan. https://files.ontario.ca/ar-2001_ard_report_tagged_final-s.pdf Hankins, Rebecca, and Miguel Juárez. 2015. Where Are All the Librarians of Color? The Experiences of People of Color in Academia. Edited by Rebecca Hankins and Miguel Juárez. Sacramento, CA: Library Juice Press.

Hathcock, April. 2015. "White Librarianship in Blackface: Diversity Initiatives in LIS." In the Library with the Lead Pipe.

http://www.inthelibrarywiththeleadpipe.org/2015/lis-diversity/.

Hathcock, April, and Stephanie Sendaula. 2017. "Mapping Whiteness at the Reference Desk." In Topographies of Whiteness: Mapping Whiteness in Library and Information Science, edited by Gina Schlesselman-Tarango, 251-60. Sacramento, CA: Library Juice Press.

Heritage Canada. 2019. Building a Foundation for Change: Canada's Anti-Racism Strategy 2019-2022. Ottawa: Canadian Heritage.

https://www.canada.ca/en/canadian-heritage/campaigns/anti-racismengagement/anti-racism-strategy.html.

Hill, Evan, Ainara Tiefenthäler, Christiaan Triebert, Drew Jordan, Haley Willis, and Robin Stein. 2020. "8 Minutes and 46 Seconds: How George Floyd Was Killed in Police Custody." New York Times. https://www.nytimes.com/2020/05/31/us/georgefloyd-investigation.html

Hogarth, Kathy, and Wendy L. Fletcher. 2018. A Space for Race: Decoding Issues of 
Racism, Multiculturalism and Post-Colonialism in the Quest for Belonging. Oxford University Press.

Honma, Todd. 2005. "Trippin' Over the Color Line: The Invisibility of Race in Library and Information Studies." InterActions: UCLA Journal of Education and Information Studies 1 (2). https://escholarship.org/uc/item/4nj0w1mp.

Honma, Todd. 2017. Forward to Topographies of Whiteness: Mapping Whiteness in Library and Information Science. Edited by Gina Schlesselman-Tarango. Sacramento, CA: Library Juice Press.

Howard, Tyrone C., and Oscar Navarro. 2016. "Critical Race Theory 20 Years Later." Urban Education 51 (3): 253-273. DOI: 10.1177\%2F0042085915622541

Hudson, David James. 2017a. "On 'Diversity' as Anti-Racism in Library and Information Studies: A Critique." Journal of Critical Library and Information Studies 1 (1). https://doi.org/10.24242/jclis.v1i1.6.

Hudson, David James. 2017b. "The Whiteness of Practicality." In Topographies of Whiteness: Mapping Whiteness in Library and Information Science, edited by Gina Schlesselman-Tarango. Sacramento, CA: Library Juice Press.

Jackson, Andrew P., Julius Jefferson, and Akilah Nosakhere. 2012. The 21st-Century Black Librarian in America: Issues and Challenges. Edited by Andrew P. Jackson, Julius C. Jefferson Jr., and Akilah S. Nosakhere. Lanham: Scarecrow Press, Inc.

Kumasi, Kafi. 2012. "Roses in the Concrete: A Critical Race Perspective on Urban Youth and School Libraries." Knowledge Quest 40 (5): 32-37.

https://digitalcommons.wayne.edu/slisfrp/71/

Kumasi, Kafi, and Sandra Hughes-Hassell. 2017. "Shifting Lenses on Youth Literacy and Identity." Knowledge Quest 45 (3): 12-21.

https://digitalcommons.wayne.edu/slisfrp/154/

Lipsitz, George. 2019. "The Sounds of Silence: How Race Neutrality Preserves White Supremacy." In Seeing Race Again: Countering Colorblindness Across the Disciplines, edited by Kimberlé Crenshaw, 23-51. Oakland, California: University of California Press.

London Free Press. 2020. "London's 10,000-strong Black Lives Matter Protest. https://lfpress.com/gallery/photos-londons-10000-strong-black-lives-matterprotest

Mendelsohn Aviv, Noa. "The Hard Truth about Regis Korchinski-Paquet." Toronto Star, June 9, 2020.

https://www.thestar.com/opinion/contributors/2020/06/09/the-hard-truth-aboutregis-korchinski-

paquet.html\#: : :text=At\%20Canadian\%20law\%20schools\%2C\%20students, is\% 20proven\%20again\%20and\%20again.

Nova Scotia. 2020. Premier Delivers Apology, Sets Course for Fundamental Change in Public Safety. Province of Nova Scotia. https://novascotia.ca/news/release/?id=20200929002.

Olson, Hope A. 2001. "The Power to Name: Representation in Library Catalogs." Signs: Journal of Women in Culture and Society 26 (3): 639-668.

https://www.jstor.org/stable/3175535. 
Pawley, Christine. 2006. "Unequal Legacies: Race and Multiculturalism in the LIS Curriculum." The Library Quarterly: Information, Community, Policy 76 (2): 14968. http://doi.org/10.1086/506955.

Potts, Karen L., and Leslie Brown. n.d. "Becoming an Anti-Oppressive Researcher." In Research as Resistance: Revisiting Critical, Indigenous, and Anti-Oppressive Approaches, edited by Leslie Brown and Susan Strega. Toronto, ON: Canadian Scholars' Press.

Schlesselman-Tarango, Gina. 2017. Introduction to Topographies of Whiteness: Mapping Whiteness in Library and Information Science. Edited by Gina Schlesselman-Tarango. Sacramento, CA: Library Juice Press.

Schmidt, Jane. 2019. "White Fragility and Privilege in Librarianship." Canadian Journal of Academic Librarianship 4: 1-7. https://doi.org/10.33137/cjal-rcbu.v4.32166

Truth and Reconciliation Commission Canada. 2015. The Survivors Speak: A Report of the Truth and Reconciliation Commission of Canada. Winnipeg, Manitoba: Truth and Reconciliation Commission of Canada.

VanScoy, Amy, and Kawanna Bright. 2019. "Articulating the Experience of Uniqueness and Difference for Librarians of Color." The Library Quarterly 89 (4): 285-97. https://doi.org/10.1086/704962.

Wane, Njoki N. 2020. "COVID-19: The Pandemic and Histories of Inequities Unveiled Impact on Black communities." Royal Society of Canada. https://rscsrc.ca/en/covid-19/covid-19-pandemic-histories-inequities-unveiled-impact-blackcommunities.

Williams, Malcolm, and W. Paul Vogt. 2011. The SAGE Handbook of Innovation in Social Research Methods. Sage Publications. 